\title{
Effect of processing of oilseed meals on the apparent ileal protein digestibility and performance in pigs
}

\author{
T.G. Hulshof ${ }^{1,2}$, P. Bikker ${ }^{l}$ and A.F.B. van der Poel ${ }^{2}$ \\ ${ }^{1}$ Wageningen UR Livestock Research, Edelhertweg 15, 8219 PH, Lelystad, the Netherlands; \\ tetske.hulshof@wur.nl \\ ${ }^{2}$ Animal Nutrition Group, Wageningen University, De Elst 1, 6708 WD, Wageningen, the Netherlands
}

\section{Introduction}

Feed ingredients, e.g. oil seed by-products, generally have undergone several processing steps before inclusion in animal diets. Processing of feed ingredients and diets can result in conformational changes of protein structure, the formation of Maillard reaction products and cross-links between amino acids (Bender, 1972). These changes affect protein quality and the latter two reactions especially reduce the amount of the essential amino acid lysine (Mauron, 1990). The effects on protein quality may result in an impaired pig performance presumably related to a decrease in protein, amino acid and lysine digestibility as found for processed diets (González-Vega et al., 2011). The aims of this research were to determine the effects of processing of two oil seed by-products, i.e. soybean meal (SBM) and rapeseed meal (RSM), on apparent ileal crude protein, amino acid and lysine digestibility and performance in growing pigs and to derive criteria to evaluate protein quality in heat treated ingredients. First results of ileal crude protein digestibility are presented here.

\section{Material and methods}

Ten barrows (initial BW $24.8 \pm 0.28 \mathrm{~kg}$ ) were suited with a SICV cannula (Mroz et al., 1996) and individually housed in metabolism cages. Four experimental diets (Table 1) were used, consisting of a basal N-free diet supplemented with 35\% (un)processed SBM or RSM in combination with 7 or $5 \%$ of the sugar rich compound Xylig ${ }^{\mathrm{TM}}$, respectively. SBM and RSM were used as purchased or toasted after mixing with Xylig ${ }^{\mathrm{TM}}$, in order to induce changes in protein quality. The RSM diets were supplemented with synthetic lysine, threonine and tryptophan to levels corresponding to the levels in the SBM diets. In all diets $\mathrm{Cr}_{2} \mathrm{O}_{3}$ was added as indigestible marker to calculate the apparent ileal crude protein digestibility (AID CP). The experiment consisted of a cross-over design with three periods of 14 days. Feed was provided twice a day at 2.8 times maintenance energy. Ileal chyme was collected during 12 hours on days 9 and 11 of each period and analysed for $\mathrm{CP}$, amino acids and $\mathrm{Cr}_{2} \mathrm{O}_{3}$. The gain:feed (GF) ratio was calculated as measure for nutrient utilization. The proc mixed procedure in SAS (2008) was used to test for the fixed effects of feed ingredient, processing

Table 1. Nutrient composition $(\mathrm{g} / \mathrm{kg}$ ) of the experimental diets containing either unprocessed or toasted soybean meal (SBM) or rapeseed meal (RSM).

\begin{tabular}{|c|c|c|c|c|}
\hline \multirow[t]{2}{*}{ Nutrient } & \multicolumn{2}{|l|}{ SBM } & \multicolumn{2}{|l|}{ RSM } \\
\hline & Unprocessed & Toasted & Unprocessed & Toasted \\
\hline Dry matter & 888 & 895 & 888 & 893 \\
\hline Ash & 45 & 46 & 39 & 40 \\
\hline Crude protein & 168 & 170 & 121 & 125 \\
\hline Crude fibre & 12 & 11 & 43 & 47 \\
\hline Crude fat & 30 & 27 & 32 & 35 \\
\hline Starch & 423 & 423 & 433 & 436 \\
\hline Sugars & 142 & 136 & 135 & 129 \\
\hline
\end{tabular}


treatment, and their interaction on AID CP and GF ratio, with period and animal in the random statement. $P$-values $<0.05$ were assumed to be significant.

\section{Results and discussion}

The results of the AID CP and GF ratio are given in Table 2. The interaction between feed ingredient and processing treatment was not significant for $\operatorname{AID~CP}(P=0.40)$ and $\mathrm{GF}$ ratio $(P=0.68)$ indicating that processing has similar effects on both characteristics for SBM and RSM diets. The animals fed the RSM diets had a significantly lower AID CP than the animals fed the SBM diets. This agrees with other studies indicating that RSM in general has a lower AID CP than SBM (Grala et al., 1998). The type of feed ingredient did not influence the GF ratio despite the lower AID CP content, presumably because of the supplementation of the RSM diets with synthetic lysine, threonine and tryptophan. Processing of the SBM and RSM reduced the AID CP as well as the GF ratio. The lower efficiency of nutrient utilization for tissue deposition as indicated by the reduction in GF ratio might be caused by the reduction in protein digestibility. In conclusion, additional processing of SBM and RSM, i.e. mixing with a sugar rich compound and toasting, reduced the crude protein digestibility and nutrient utilization as indicated by the GF ratio. The effects of individual amino acids will be further examined.

Table 2. Effect of feed ingredient, i.e. soybean meal (SBM) or rapeseed meal (RSM), and processing treatment, i.e. none or toasting, on apparent ileal crude protein digestibility (AID CP) and gain:feed (GF) ratio in pigs.

\begin{tabular}{llllll} 
SBM & RSM & SEM & P-value & \\
\cline { 1 - 1 } \cline { 5 - 6 } Unprocessed Toasted & & Unprocessed & Toasted & $\begin{array}{l}\text { Feed } \\
\text { ingredient }\end{array} \begin{array}{l}\text { Processing Interaction } \\
\text { treatment }\end{array}$
\end{tabular}

$\begin{array}{lcccccccc}\text { AID CP } & 78.4^{\mathrm{c}} & 66.0^{\mathrm{a}} & 65.6^{\mathrm{a}} & 56.1^{\mathrm{b}} & 1.68 & <0.0001 & <0.0001 & 0.40 \\ \text { GF ratio } & 0.48^{\mathrm{a}} & 0.43^{\mathrm{ac}} & 0.45^{\mathrm{a}} & 0.38^{\mathrm{bc}} & 0.024 & 0.10 & 0.02 & 0.68\end{array}$

a,b,c different superscripts in the same row indicate significantly $(P<0.05)$ different values.

\section{Acknowledgements}

The authors gratefully acknowledge the financial support from the Wageningen UR 'IPOP Customized Nutrition' programme financed by Wageningen UR, the Dutch Ministry of Economic Affairs, Agriculture \& Innovation, WIAS, Agrifirm Innovation Center, ORFFA Additives BV, Ajinomoto Eurolysine s.a.s and Stichting VICTAM BV.

\section{References}

Bender, A.E., 1972. Processing damage to protein food: a review. J. Food Technol. 7, 239-250.

González-Vega, J.C., B.G. Kim, J.K. Htoo, A. Lemme and H.H. Stein, 2011. Amino acid digestibility in heated soybean meal fed to growing pigs. J. Anim. Sci. 89, 3617-3625.

Grala, W., M. Verstegen, A. Jansman, J. Huisman and P. van Leeusen, 1998. Ileal apparent protein and amino acid digestibilities and endogenous nitrogen losses in pigs fed soybean and rapeseed products. J. Anim. Sci. 76, 557-568.

Mauron, J., 1990. Influence of processing on protein quality. J. Nutr. Sci. Vitaminol. 36, S57-S69.

Mroz, Z., G.C.M. Bakker, A.W. Jongbloed, R.A. Dekker, R. Jongbloed and A. van Beers, 1996. Apparent digestibility of nutrients in diets with different energy density, as estimated by direct and marker methods for pigs with or without ilea-cecal cannulas. J. Anim. Sci. 74, 403-412.

SAS, 2008. Release 9.2. SAS Inst. Inc., Cary, NC, USA. 